\title{
Temporal relation of antigenaemia and loss of antibodies to core antigens to development of clinical disease in HIV infection
}

\author{
COURT PEDERSEN, CARSTEN MØLLER NIELSEN, BENT FABER VESTERGAARD, \\ JAN GERSTOFT, KIM KROGSGAARD, JENS OLE NIELSEN
}

\begin{abstract}
A total of 276 sequential serum samples from 34 men with antibodies to the human immunodeficiency virus (HIV) followed up for two to seven years were analysed for HIV antigen and antibodies to the viral core and envelope proteins. Results were correlated with clinical outcome and CD4 T lymphocyte count. Both antigenaemia and the disappearance of antibodies to the core protein were associated with development of the acquired immune deficiency syndrome (AIDS) or AIDS related complex and depletion of CD4 cells. Thus AIDS or AIDS related complex developed in eight out of 16 patients with antigenaemia compared with one out of 18 patients without antigenaemia. Low counts of CD4 cells $\left(<0.5 \times 10^{\circ} / 1\right)$ were found in 14 of the 16 patients with antigenaemia and five of the 18 without antigenaemia. Nine patients seroconverted to HIV during the study; two of these developed antigenaemia 14 and 16 months after the estimated time of seroconversion.
\end{abstract}

These results show that the late stages of HIV infection are characterised by increased production of antigen and a decrease in antibodies directed against the core protein. Antigenaemia indicates a poor prognosis; and as the antigen test is simple to do and interpret, it may therefore be useful for selecting patients for antiviral treatment.

\footnotetext{
Department of Infectious Diseases, Hvidovre Hospital, Copenhagen, Denmark

COURT PEDERSEN, MD, research fellow

JAN GERSTOFT, MD, PHD, registrar

KIM KROGSGAARD, MD, research fellow

JENS OLE NIELSEN, MD, PHD, head of department
}

Retrovirus Laboratory, Statens Seruminstitut, Copenhagen, Denmark CARSTEN MØLLER NIELSEN, MD, registrar

BENT FABER VESTERGAARD, MD, PHD, head of department

Correspondence to: Dr Court Pedersen, Department of Infectious Diseases, 144 Hvidovre Hospital, Hvidovre, 2650-Denmark.

\section{Introduction}

After acute infection with the human immuodeficiency virus (HIV) the viral core antigen p24 is detectable in serum..$^{1-3}$ When antibodies develop antigen often becomes undetectable. In the late stages of HIV infection an association between HIV antigenaemia and progression to overt HIV related disease has been reported. ${ }^{45}$ Though prospective studies on the occurrence of HIV specific antibodies and antigen have been performed during seroconversion with follow up for one year, ' information on the temporal association between HIV antigen in serum, antibody profile, and the immunological and clinical state of patients during long term follow up is scarce. We report the findings in sequential serum samples from 34 men followed up for two to seven years with respect to the occurrence of HIV antigen and antibody profile and relate these to the immunological and clinical outcome.

\section{Patients and methods}

Sequential serum samples were studied from 34 men in whom HIV antibodies were detected before 31 December 1984. Three of the patients were haemophiliacs and the other 31 homosexuals.

From late 1984 serum samples were collected prospectively about every four months and before then about every six months for evaluation of the efficacy of factor VIII preparation, a prospective study of hepatitis B, and as part of screening for the acquired immune deficiency syndrome (AIDS) ${ }^{6}$ Altogether 276 samples were examined from the 34 patients (median 7 (range 5-14) from each patient). With the exception of generalised lymphadenopathy, which was present in 20 patients, none had symptoms at the time of the first serum sample.

The study group was followed up for a median of 36 months (range 25-84). Clinical symptoms during follow up were graded according to the system used by the Centers for Disease Control for HIV infection. ${ }^{7}$ AIDS related complex in this study includes patients in group IV, subgroups A, C-2, and $\mathrm{E}$ (one patient with poorly differentiated Hodgkin's lymphoma). None of the patients received antiviral treatment for HIV during the study.

All serum samples were tested for antibodies to HIV by a commercially available enzyme linked immunosorbent assay (ELISA; Vironostika, Organon). In all cases the serological diagnosis of HIV infection was confirmed by immunoblotting. Serum samples were assayed for HIV antigen by a biotin-avidin potentiated double antibody sandwich enzyme 
immurioassay using human IgG of high antibody titre as both capture and indicator antibodies. Results were expressed as the optical density of the test well divided by the optical density of the control well (T:C ratio). Samples giving $\mathrm{T}: \mathrm{C}$ ratios $>2 \cdot 0$ were scored positive provided that the optical density of the test well was $>0 \cdot 1$. Details of the method have been described ${ }^{8}(\mathrm{C} M$ Nielsen, P Feorino, C Pedersen, B F Vestergaard, paper in preparation).

Antibodies to HIV envelope and core antigens were assayed by a commercially available competitive enzyme immunoassay (Abbott Laboratories) employing recombinant HIV antigens. The core antigen contains the entire p24gag gene product as well as part of the p15 and p18gag gene products. The envelope antigen contains the entire p4lenv gene product as well as part of the gp120env gene product. ${ }^{9}$ In this paper antibodies to the core antigens are designated anti-p24 and antibodies to the envelope antigens anti-p41.

$\mathrm{T}$ cell subsets were quantified by using monoclonal antibodies, as described. ${ }^{10}$ Thus CD4 $\mathrm{T}$ lymphocytes were counted by using Leu3 antibodies.

Statistical analysis was by the Mann-Whitney rank sum test. Proportions were compared by the $\chi^{2}$ test or Fisher's exact test.

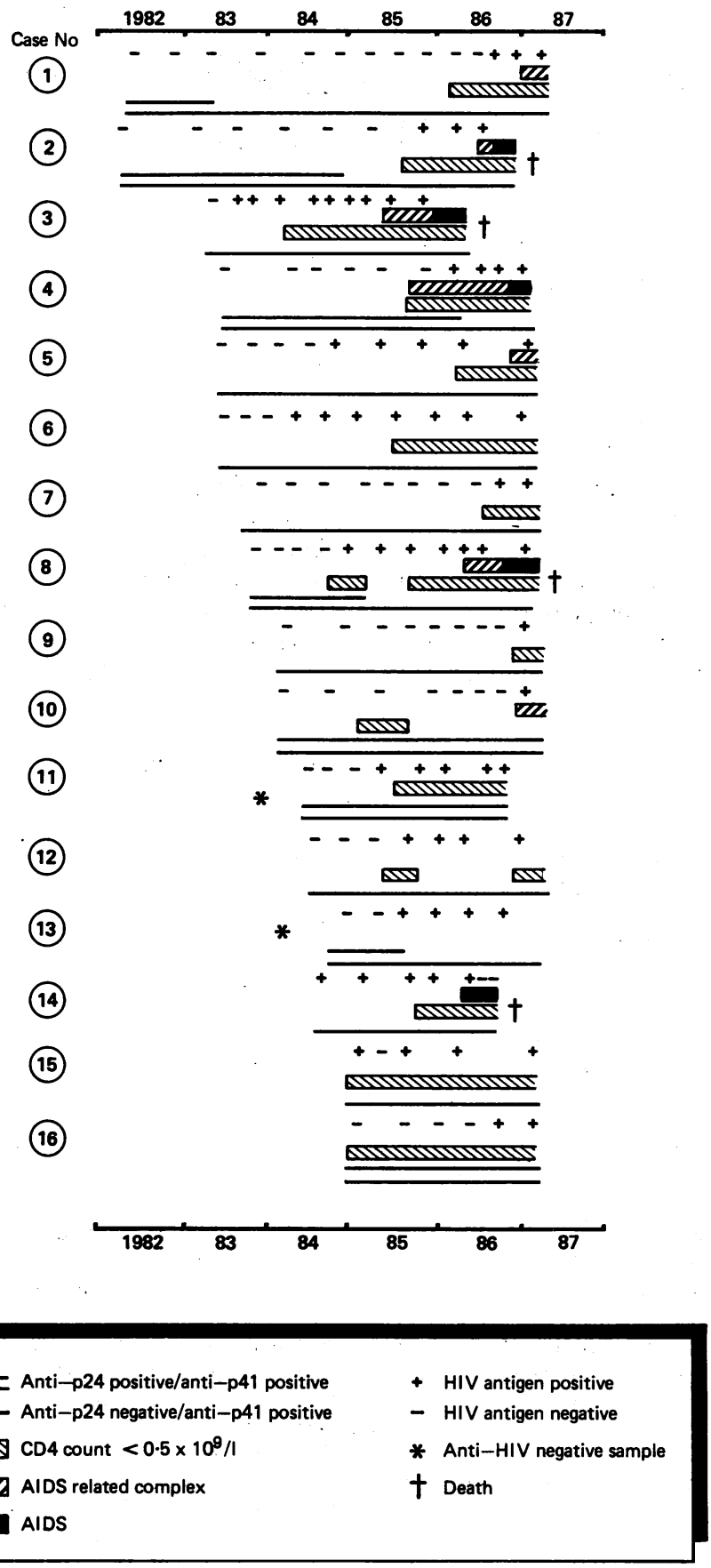

FIG 1-HIV antigenaemia, antibody profile, CD4 count, and clinical outcome in 16 anti-HIV positive patients with antigenaemia at some time during follow up.

\section{Results}

HIV antigen in serum was detected at least once in $16(47 \%)$ of the 34 subjects. The median follow up time was 39 months (range 26-58) in those with detectable antigen and 32 months (25-84) in those without antigenaemia. This difference was not significant. Of the 16 patients with antigenaemia, eight developed AIDS or AIDS related complex (table). Fourteen $(88 \%)$ had low counts of CD4 cells at the end of follow up. By contrast, only five $(28 \%)$ of the 18 patients without antigenaemia had low counts of CD4 cells and only one patient from this group developed AIDS. Clinical disease and depletion of CD4 cells were significantly associated with antigenaemia $(p<0 \cdot 01)$.

In the group of patients with antigenaemia the median antigen level $(T: C$ ratio) was $5 \cdot 5$ (range $4 \cdot 1-17 \cdot 2$ ) at the time of diagnosis in those with AIDS or AIDS related complex, as compared with $2 \cdot 7$ (range $2 \cdot 1-5 \cdot 4$ ) at the end of follow up in those who remained asymptomatic $(p<0.01)$. Once developed, antigenaemia persisted in all but two of the patients. One patient (case 15; see fig 1) had one negative sample after the appearance of antigenaemia; in this patient, however, both the positive and negative samples gave borderline T:C ratios. Another patient (case 14) became antigen negative after the diagnosis of AIDS and remained so until his death. Shortly before becoming antigen negative this patient had received cytotoxic treatment for metastatic Kaposi's sarcoma.

All 256 anti-HIV positive serum samples (ELISA) from the 34 patients were anti-p41 positive. By contrast, anti-p24 was undetectable or disappeared in 12 patients, 11 of whom were or became antigen positive. Loss of anti-p24 was significantly associated with the development of clinical disease and depletion of $\mathrm{CD} 4$ cells (table).

Figure 1 shows the combined results for HIV antigenaemia, antibody profile, CD4 count, and clinical outcome in the 16 antigen positive patients. The onset of AIDS and AIDS related complex was preceded by antigenaemia by a median of 24 (range 9-29) and $13(0 \cdot 27)$ months, respectively. Five patients had antigenaemia and detectable anti-p24 concomitantly. The median antigen level ( $T: C$ ratio) was 4.5 (range $2 \cdot 1-33.0$ ) in anti-p24 negative samples compared with $3 \cdot 3(2 \cdot 1-6 \cdot 6)$ in anti-p24 positive samples $(p<0.01)$. The patient without detectable antigenaemia who developed AIDS was persistently anti-p24 positive.

In nine patients seroconversion occurred. The median interval between the last negative and first positive samples was nine months (range 2-14). The median follow up (time from the first anti-HIV positive sample to the end of follow up) was 40 months (26-84). Two of these patients developed antigenaemia 14 and 16 months after the estimated time of seroconversion (interval between the last negative and first positive sample divided by 2). The remaining seven patients were persistently antigen negative. In none of the seroconverters was antigenaemia recorded in connection with seroconversion.

Clinical outcome and CD4 count at end of follow up in 34 subjects with HIV infection with or without HIV antigen or anti-p24 in serum. Figures are numbers of subjects

\begin{tabular}{lccccc}
\hline & $\begin{array}{c}\text { No } \\
\text { studied }\end{array}$ & AIDS & $\begin{array}{c}\text { AIDS related } \\
\text { complex }\end{array}$ & CD4 $<0.5 \times 10^{9} / 1$ & CD4 $<0.3 \times 10^{9} / 1$ \\
\hline HIV antigen positive & 16 & 5 & 3 & 14 & 10 \\
HIV antigen negative & 18 & 1 & 0 & 5 & 1 \\
Anti-p24 positive & 22 & 1 & 1 & 8 & 3 \\
Anti-p24 negative & 12 & 5 & 2 & 11 & 8 \\
\hline
\end{tabular}

\section{Discussion}

This study shows that HIV antigenaemia and loss of antibody to the viral core protein are associated with the development of clinical disease in patients with HIV infection. Half the patients with antigenaemia developed AIDS or AIDS related complex and most of the remaining antigen positive subjects, though asymptomatic, had signs of immunodeficiency as judged by low counts of CD4 $\mathrm{T}$ lymphocytes. Our findings agree with those of others. Thus Kenny et al in a study of 32 patients with AIDS associated complex found progression to AIDS to be associated with HIV antigenaemia or anti-p24 negativity, or both, ${ }^{5}$ and a three year study by Weber et al showed a significant association of declining anti-p24 titre with progression of disease and, as in our study, that serological changes often preceded disease progression by more than 24 months. ${ }^{.1}$ Weber $e t$ al did not test serum for HIV antigen.

From our data and other studies of acute ${ }^{1-3}$ and chronic HIV infection ${ }^{4512-15}$ the serological profile of HIV infection in most patients appears to be as shown in figure 2 . In a minority of 


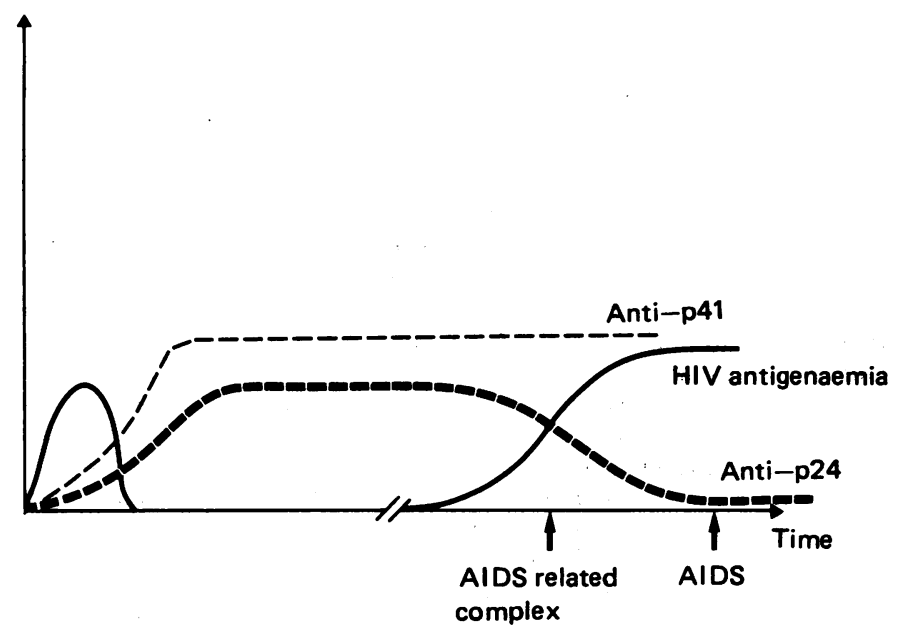

FIG 2-Serological profile of HIV infection.

patients, however, HIV antigen remains detectable after the primary infection' (Pedersen et al, unpublished).

The serological events during acute infection resemble those of other viral infections associated with antigenaemia, but the recurrence of antigenaemia and loss of anti-p24 during late stages of the infection are less readily explained. Loss of anti-p24 due to defective $B$ cell function is unlikely to be the initial event, as the production of antibodies directed against other HIV antigens remains intact. More probably loss of anti-p24 is secondary to the formation of antigen-antibody complexes due to increasing amounts of antigen in the late stages of the infection. This hypothesis is supported by the finding of HIV antigen in polyethylene glycol precipitated immune complexes both in patients with anti-p24 and in patients without detectable anti-p24 in serum. ${ }^{16}$

Our study shows that some patients develop antigenaemia within two years of infection while others remain healthy without antigenaemia for up to seven years. The reasons for the different courses remain obscure. Further studies of the serological profile in HIV infection, with special attention paid to events preceding antigenaemia and loss of anti-p24, may establish the role of possible cofactors for the progression of clinical disease.
Recurrence of HIV antigenaemia seems to indicate a poor prognosis. Kaplan-Meier curves (data not shown) show that $49 \%$ of patients will develop AIDS within two years from the reappearance of antigenaemia. This must be added to the long list of clinical, histological, immunological, and serological indicators of a bad prognosis. ${ }^{17}$ The ideal prognostic test must be simple to do and interpret. The antigen test fulfils these criteria and has the further advantage that it can be used in the form of a filter paper test, ${ }^{8}$ which may be of value in developing countries.

This study was supported by grants from the Michaelsen Foundation and the Danish State Medical Research Council.

\section{References}

1 Goudsmit J, Paul DA, Lange JMA, et al. Expression of human immunodeficiency virus antigen in serum and cerebrospinal fluid during acute and chronic infection. Lancet 1986;ii:177-80.

2 Allain JP, Laurian Y, Senn D. Serological markers in early stages of human immunodeficiency virus infection in haemophiliacs. Lancet 1986;ii:1233-6.

3 Wall RA, Denning DW, Amos A. HIV antigenaemia in acute HIV infection. Lancet 1987; ;:566.

4 Lange JMA, Paul DA, Huisman HG, et al. Persistent HIV antigenaemia and decline of HIV core antibodies associated with transition to AIDS. Br Med F 1986;293:1459-62.

5 Kenny C, Parkin J, Underhill G, et al. HIV antigen testing. Lancet 1987;i:565-6.

6 Pedersen $\mathrm{C}$, Kolby $\mathrm{P}$, Sindrup $\mathrm{JH}$, et al. Immunological studies in homosexual men with and without antibodies to human T-cell lymphotropic virus type III. Dan Med Bull 1986;33:270-2.

7 Centers for Disease Control, Atlanta. Classification system for human T-lymphotropic virus type III/ymphadenopathy associated virus infection. Ann Intern Med 1986;105:234-7.

8 Nielsen CM, Bygbjerg IC, Vestergaard BF. Detection of HIV antigens in eluates from whole blood collected on filter paper. Lancet 1987; i:566-7.

9 Dawson GJ, Heller JS, Decker RH, Valdivia LA. Confirmatory assay for antibodies to HTLV III Programs and abstracts of the II international conference on AIDS, Paris, 1986. Paris: Facimprim 1986:abstract No 642.

10 Gerstoft J, Malchow-Møller A, Bygbjerg I, et al. Severe acquired immunodeficiency in European homosexual men. BrMed f 1982;285:17-9.

11 Weber JN, Weiss RA, Roberts C, et al. Human immunodeficiency virus infection in two cohorts of homosexual men: neutralising sera and association of anti-gag amtibody with prognosis. Lancet 1987; i:119-22.

12 Kalyanaraman VS, Cabradilla CD, Getchell JP, et al. Antibodies to the core protein of lymphadenopathy-associated virus (LAV) in patients with AIDS. Science 1984;225:321-3.

13 Lange JMA, Coutinho RA, Krone WJA, et al. Distinct IgG recognition patterns during progression of subclinical and clinical infection with lymphadenopathy associated virus/human T-lymphotropic virus. BrMed f 1986;292:228-30.

14 Goudsmit J, Lange JMA, Paul DA, Dawson GJ. Antigenemia and antibody titers to core and envelope antigens in AIDS, AIDS-related complex, and subclinical human immunodeficiency virus infection. $\mathcal{I}$ Infect Dis 1987;155:558-60.

15 Biggar BJ, Melbye M, Ebbesen P, et al. Variation in human T lymphotropic virus III (HTLV III) antibodies in homosexual men: decline before onset of illness related to acquired immune deficiency syndrome (AIDS). Br Med F 1985;291:997-8.

16 Lange J, Goudsmit J. Decline of antibody reactivity to HIV core protein secondary to increased production of HIV antigen. Lancet 1987; i:448.

17 Anonymous. Who will get AIDS? [Editorial.] Lancet 1986;ii:953-4.

(Accepted 21 fuly 1987)

\title{
Risk of AIDS related complex and AIDS in homosexual men with persistent HIV antigenaemia
}

\author{
F DE WOLF, JAAP GOUDSMIT, DEBORAH A PAUL, JOEP M A LANGE, \\ CHRISTA HOOIJKAAS, PETER SCHELLEKENS, ROEL A COUTINHO, \\ JAN VAN DER NOORDAA
}

\begin{abstract}
One hundred and ninety eight men seropositive for human immunodeficiency virus (HIV) antibody and 58 HIV antibody seroconverters were studied for an average of 19.3 (SEM $0.5)$ months to assess the relation between HIV antigenaemia and the risk of developing the acquired immune deficiency syndrome (AIDS) and AIDS related complex. Forty (20.2\%) of the 198 HIV antibody seropositive men were antigen positive at entry and remained so during follow up. Eight $(13.8 \%)$ of the $58 \mathrm{HIV}$ antibody seroconverters and $20(12.7 \%)$ of the remaining $158 \mathrm{HIV}$ antibody seropositive men became antigen positive during follow up, resulting in an end point attack rate for HIV antigenaemia of $14 \cdot 3 \%$. AIDS related complex was diagnosed in $25(15.8 \%)$ of the
\end{abstract}

HIV antigen negative men and in $14(20.7 \%)$ of the HIV antigen positive men. AIDS was diagnosed in 15 men, resulting in an end point attack rate for AIDS of $23.9 \%$ in the HIV antigen positive group and $1.3 \%$ in the antigen negative group.

HIV antibody seropositive men without symptoms but with persistent HIV antigenaemia are at increased risk of developing AIDS and AIDS related complex.

\section{Introduction}

Human immunodeficiency virus (HIV) is the causative agent of the acquired immune deficiency syndrome (AIDS) and related 